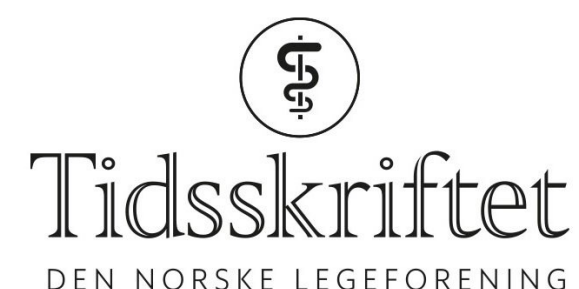

\title{
Rettelse: Notis om alkoholforbud i USA
}

RETTELSE

JULIE DIDRIKSEN

Tidsskr Nor Legeforen 2019; 139. doi:10.4045/tidsskr.18.0976.

I Tidsskriftet nr. 9/2019 på s. 86o skal den nest siste setningen i ingressen være: Selv om et av resultatene var at annen kriminalitet, for eksempel smugling, eksploderte, førte det også til at alkoholinntaket sank.

Vi beklager feilen, den er rettet på nett.

Publisert: 22. august 2019. Tidsskr Nor Legeforen. DOI:10.4045/tidsskr.19.0529

(C) Tidsskrift for Den norske legeforening 2020. Lastet ned fra tidsskriftet.no 